\title{
MANFAAT SERTA KENDALA MENERAPKAN FLASHCARD PADA PELAJARAN MEMBACA PERMULAAN
}

\author{
Ashiong P. Munthe \\ ashiong.munthe@uph.edu \\ Fakultas IImu Pendidikan, Universitas Pelita Harapan \\ Jesica Vitasari Sitinjak \\ jesicasitinjak2@gmail.com \\ Sekolah Lentera Harapan, Mamit, Papua
}

\begin{abstract}
The beginning reading is the initial stage of reading learning that must be taught from an early age, because it is the basis for students to be able to move to the reading comprehension stage. In the reading beginning, students are taught to recognize letters and letter sounds, stringing letters into syllables, words to compose sentences. When implementing the reading beginning with flashcard there are certainly benefits and constraints encountered. Thus, this research was conducted to describe the benefits and constraints encountered when applying a flascard to the beginning reading learning. The research method used is qualitative descriptive. Qualitative descriptive is an effort to explain facts, data, or objects, qualitatively in the form of language or discourse by interpreting appropriately and systematically. Data is displayed not in the form of quantitative numbers. This research was conducted in one of the private schools in Mamit, Papua. The class observed was grade 1 elementary school. The benefits of applying flashcard to the beginning reading learning is able to attract students' attention, students are not nervous while reading, and help students remember words more easily. While the constraints in implementing flashcards is that it takes a long time.
\end{abstract}

\section{Keywords: Flashcard, Reading, The Beginning Reading}

\begin{abstract}
ABSTRAK
Membaca permulaan merupakan tahap awal dari pembelajaran membaca yang harus diajarkan sejak usia dini, karena hal tersebut merupakan dasar bagi siswa untuk dapat melangkah kepada tahap membaca pemahaman. Saat membaca permulaan, siswa diajarkan untuk mengenal huruf dan bunyi huruf, merangkai huruf menjadi suku kata, kata hingga menyusun kalimat. Saat menerapkan membaca permulaan dengan flashcard tentunya ada manfaat dan kendala yang ditemui. Dengan demikian, penelitian ini diadakan untuk menguraikan manfaat dan kendala yang ditemui saat menerapkan flascard pada pembelajarana membaca permulaan. Metode penelitian yang digunakan adalah deskriptif kualitatif.
\end{abstract}


Deskriptif kualitatif adalah upaya menjelaskan fakta, data, atau objek, secara kualitatif dalam bentuk bahasa atau wacana dengan menginterpretasi secara tepat dan sistematis. Data ditampilkan bukan berupa angka-angka kuantitatif. Penelitian ini dilakukan di salah satu sekolah swasta yang ada di Mamit, Papua. Kelas yang di observasi adalah kelas 1 Sekolah Dasar. Manfaat dari penerapan flashcard pada pembelajaran membaca Permulaan adalah mampu menarik perhatian siswa, siswa tidak gugup ketika membaca, dan membantu siswa lebih mudah mengingat kata. Sedangkan kendala dalam penerapan flashcard adalah membutuhkan waktu yang lama.

\section{Kata Kunci: Flashcard, Membaca, Membaca Permulaan}

\section{Pendahuluan}

Saat mengajar, guru harus memiliki kepekaan, yaitu peka atas kebutuhan belajar siswa, peka atas lingkungan belajar, peka terhadap budaya dan sosial siswa. Dengan adanya kepekaan tersebut, guru dapat memahami dan menangkap esensi kebutuhan belajar siswa seutuhnya untuk difasilitasi. Untuk mampu memfasilitasi pembelajaran yang sesuai kebutuhan belajar siswa, maka guru sangat dituntut untuk kreatif dan aktif dalam pembelajaran agar materi ajar dapat tersampaikan dengan baik. Untuk memenuhi kebutuhan belajar siswa, guru harus mencari metode yang sesuai dengan konteks siswa, lingkungan siswa dan ketersediaan sarana dan prasarana yang mendukung metode tersebut.

Khusunya saat mengajar anak usia dini yaitu dari usia 0-8 tahun sangat membutuhkan kreatifitas dari guru. Menurut WHO bahwa usia 0-8 tahun merupakan anak usia dini atau early childhood, seperti kutipan berikut ini "early childhood is the period from prenatal development to eight years of age" (WHO, 2012, h.5). Pada masa anak usia dini merupakan masa pertumbuhan anak serta aktif untuk mengeksplorasi berbagai kegiatan. Pada masa ini juga, perkembangan kognitif anak sangat cepat, sehingga memerlukan perhatian yang intensif. Menurut Jamaris pada masa usia ini merupakan pendidikan yang menjadi pusat perhatian para orangtua, ahli pendidikan, masyarakat, dan pemerintah (2006, hal. 1).

Terkait dengan penelitian ini yang berfokus pada siswa kelas 1 SD yang kisaran usianya adalah enam hingga delapan tahun. Jamaris (2006, hal. 26) mengatakan bahwa kemampuan kognitif anak usia akhir enam tahun, anak sudah mulai mampu membaca, menulis, dan berhitung. Artinya bahwa anak pada akhir usia enam tahun atau memasuki usia tujuh tahun seharusnya sudah memiliki kemampuan membaca. Namun, berdasarkan hasil observasi, ketika guru mengajar membaca suku kata pada siswa kelas $1 \mathrm{SD}$ 
swasta Mamit, Papua, ternyata siswa belum mampu membaca. Saat siswa disuruh membaca suku kata, siswa hanya mampu membunyikan huruf demi huruf dari suku kata yang ditunjukan. Ternyata siswa di sekolah tersebut, dengan usia enam hingga delapan tahun, belum bisa membaca.

Membaca merupakan kompetensi yang sangat penting untuk dimiliki oleh siswa. Menurut Dalman "membaca merupakan suatu kegiatan atau proses kognitif yang berupaya untuk menemukan berbagai informasi yang terdapat dalam tulisan" (2013, hal. 5). Melalui membaca siswa akan mendapat informasi, memperkaya kosa kata dan membentuk wawasan dan pengetahuan yang luas. Dengan begitu banyaknya manfaat dari membaca, sehingga menjadi suatu keniscayaan memperkenalkan dan mengajarkan membaca kepada anak sejak usia dini.

Untuk mengajari anak usia dini membaca, harus diawali dengan tahap pengenalan huruf, merangkai huruf-huruf membentuk suku kata, kata, hingga membentuk kalimat (Dalman, 2013, hal. 86). Tahap tersebut, disebut juga sebagai tahap membaca permulaan. Membaca permulaan merupakan tahap awal dari pembelajaran membaca sebagai dasar untuk melangkah pada tahap memahami bacaan atau yang biasa disebut membaca pemahaman.
Menurut teori perkembangan kognitif Piaget bahwa kisaran umur 2-7/8 tahun masuk dalam preoprasional dengan ciri-ciri menggunakan simbol atau bahasa tanda dan mulai berkembangnya konsepkonsep intuitif (Budiningsih, 2005, hal. 37). Pada fase atau tahap ini, fungsi simbolis anak berkembang dengan cepat. Fungsi simbolis berkaitan dengan kemampuan anak untuk membayangkan suatu benda atau objek secara konkret. Oleh sebab itu, perkembangan bahasa anak pada fase ini diwarnai oleh fungsi simbolis (Jamaris, 2006, hal. 33). Memperkenalkan huruf yang dilambangkan dengan simbol, kemudia dipadukan dengan gambar-gambar tertentu untuk mempermudah siswa mengingat huruf maupun kata.

Dengan pemahaman tahap perkembangan siswa seperti yang diuraikan di atas, maka guru tentunya akan jauh lebih mudah memfasilitasi siswa dalam pembelajaran. Salah satu yang bisa diupayakan guru, sesuai tahap perkembangan anak tersebut dalam pembelajaran, adalah menggunakan flashcard. Dengan menerapkan flashcard, siswa akan dituntun untuk mengenal huruf, suku kata dan kata yang disertakan gambar dari kata tersebut.

Saat menerapkan flashcard dalam penelitian untuk membaca permulaan bagi kelas $1 \mathrm{SD}$, tentunya banyak kendala dan manfaat yang diperoleh. 
Dengan adanya kendala dan manfaat yang ditemukan, maka sangat penting dalam penelitian ini untuk mengeksplorasi manfaat dan kendala dari penelarapan flashcard di kelas 1

SD tersebut. Tujuan dari penelitian ini adalah untuk menguraikan manfaat dan kendala yang ditemukan saat menerapkan flascard pada pembelajaran membaca permulaan bagi siswa kelas 1 SD.

\section{Pengertian Membaca \\ Permulaan}

Istilah membaca permulaan adalan istilah yang lazim dipakai dalam pelajaran bahasa Indonesia untuk siswa SD kelas 1. Istilah membaca permulaan dapat ditemukan dalam buku Sri Wahyuni yang berjudul "Cepat Bisa Baca" dan dalam buku Farida Rahim yang berjudul "Pengajaran membaca di sekolah dasar". Pengertian membaca permulaan, bukan pengertian harafiah benar-benar membaca kata permulaan, melainkan tahap awal dalam membaca pada pelajaran bahasa Indonesia agar siswa bisa lanjut pada tahap membaca pemahaman, sebagai lanjutan berikutnya.

Secara lengkap pada uraian berikut ini akan memaparkan secara teoritis mengenai pengertian membaca dan membaca permulaan. Pengertian membaca menurut Irdawati, Yunidar, \& Darmawan adalah "salah satu dari empat keterampilan berbahasa yang disajikan dalam pembelajaran
Bahasa Indonesia selain keterampilan menyimak, keterampilan berbicara, dan keterampilan menulis" (2017, hal. 4). Menurut Tarigan "membaca adalah suatu keterampilan yang kompleks, yang rumit, yang mencakup atau melibatkan serangkaian keterampilanketerampilan yang lebih kecil" (2008, hal. 24). Menurut Dalman (2013, hal. 5) bahwa "membaca merupakan suatu kegiatan atau proses kognitif yang berupaya untuk menemukan berbagai informasi yang terdapat dalam tulisan". Dari uraian teori tersebut dapat ditarik kesimpulan bahwa pengertian membaca adalah salah satu keterampilan berbahasa yang didukung oleh keterampilan-keterampilan

lainnya, seperti pengenalan huruf, memahami kata dengan imajinasi tertentu terhadap kata tersebut dengan tujuan untuk memeroleh informasi dari sebuah tulisan.

Pengertian membaca permulaan menurut Wahyuni adalah keterampilan sekaligus kognitif. Keterampilan diartikan pada pengenalan dan penguasaan lambang-lambang fonem, sementara kognitif diartikan pada penggunaan lambang-lambang fonem yang sudah dikenal untuk memahami makna suatu kata atau kalimat (2010, hal. 7). Menurut Syafi'ie dalam Rahim (2007, hal. 2) bahwa penekanan dalam membaca permulaan ialah proses perseptual, yaitu pengenalan korespondensi rangkaian huruf dengan bunyi- 
bunyi bahasa. Menurut Dewi (2016, hal. 942) mengatakan bahwa "membaca permulaan juga dapat diartikan sebagai kegiatan mengenal huruf dan bunyi pelafalan huruf, kemudian mengartikan rangkaian huruf menjadi kata". Rahmawati (2017, hal. 260) menambahkan dengan mengatakan bahwa "pembelajaran membaca permulaan di kelas 1 , siswa lebih banyak dituntut untuk melafalkan lambang bunyi bahasa tulis daripada untuk memahami dan menafsirkan isi bacaan". Menurut Sofiyah bahwa "pembelajaran membaca permulaan merupakan tingkatan proses pembelajaran membaca untuk menguasai sistem tulisan sebagai representasi visual bahasa" (2014, hal. 4). Menurut Kusminah mengatakan bahwa "membaca permulaan merupakan aktivitas membaca yang dilakukan oleh peserta didik untuk melafalkan huruf, suku kata, kata, frase, klausa, kalimat, dan wacana sesuai dengan intonasi dalam bacaan" (2012, hal. 115). Menurut Wati (dalam Yawu, Efendi, \& Barasandji, 2017, hal. 57) "langkah-langkah membaca permulaan adalah mengenal unsur kalimat, mengenal unsur kata, mengenal unsur huruf, merangkai huruf menjadi suku kata, dan merangkai suku kata menjadi kata".

Melalui paparan teori di atas dapat ditarik kesimpulan bahwa membaca permulaan merupakan tahap awal dalam pembelajaran membaca, khusunya bagi siswa sekolah dasar. Pada tahap ini, siswa diajari untuk mengenal huruf dan bunyi setiap huruf. Dengan mengenal huruf dan bunyi huruf, siswa dapat merangkai menjadi suku kata dan suku kata tersebut dapat dirangkai menjadi sebuah kata serta memahami makna kata tersebut. Selanjutnya, dengan mampu merangkai kata, siswa mampu menyusun kalimat hingga mampu memahami isi bacaan dengan baik.

\section{Pengertian Flashcard}

Sebenarnya untuk memahami fashcard tidaklah terlalu sulit, karena bentuknya berupa kartu yang mudah ditemukan dalam kehidupan sehari-hari. Bahan-bahanya juga relatif mudah ditemukan. Beberapa teori akan diuraikan untuk memaparkan tentang flashcard. Menurut Susilana \& Riyana mengatakan bahwa flashcard adalah media pembelajaran dalam bentuk kartu bergambar yang berukuran $25 \mathrm{x}$ $30 \mathrm{~cm}$ (2009, hal. 94). Menurut Arsyad (2011, hal. 120) mengatakan bahwa "flashcard biasanya berukuran $8 \times 12 \mathrm{~cm}$, atau dapat disesuaikan dengan besar kecilnya kelas yang dihadapi". Windura (2010, hal.138) mengatakan bahwa, "flashcard merupakan kartu bolak-balik yang sangat ampuh digunakan untuk mengingat dan mengkaji ulang dalam proses belajar". Menurut Suryana dalam Hotimah (2010, hal. 12) "Flashcard merupakan salah satu bentuk permainan edukatif berupa kartu-kartu yang memuat 
gambar dan kata yang sengaja dirancang untuk meningkatkan berbagai aspek diantaranya: mengembangkan daya ingat, melatih kemandirian, dan meningkatkan kosa kata".

Flashcard yang digunakan dalam pembelajran biasanya bertuliskan kata, sementara pada sisi lainnya ada gambar yang sesuai dengan kata. Fungsi utama dari gambar adalah untuk melatih daya ingat siswa terhadap kata yang sedang dipelajari. Dengan memanfaatkan flashcard akan memperbanyak
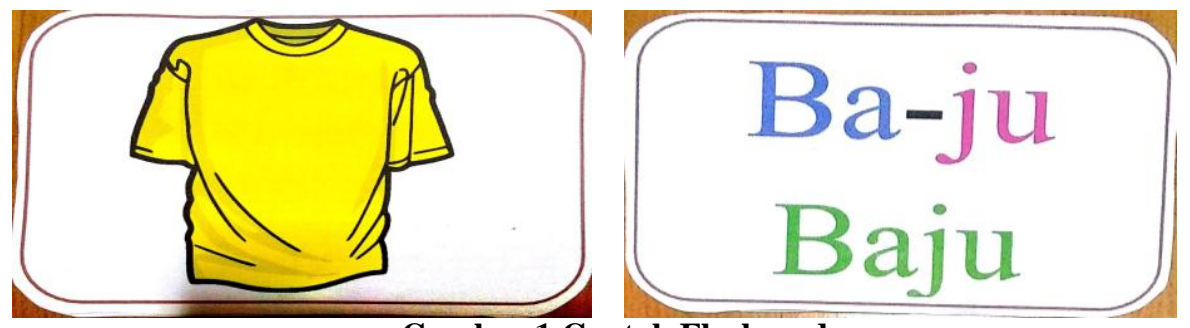

Gambar 1 Contoh Flashcard

Sumber Gambar: google.com, dari dokumen (Jesica, 2017)

memuat gambar di satu sisinya dan di sisi lainnya ada kata yang sesuai dengan gambar tersebut. Kata pada bagian depan dan gambar pada bagian belakang flashcard atau sebaliknya, disesuaikan dengan kebutuhan siswa serta materi yang akan diajarkan. Gambar yang terdapat pada satu sisi flashcard tujuannya adalah untuk mempermudah siswa mengingat dan memahami kata yang terdapat pada sisi lain flashcard. Flashcard sangat membantu siswa untuk melatih daya ingat mereka terhadap kata yang sedang dipelajari. Menggunaka flashcard dalam pembelajaran harus melihat idealnya siswa, karena flashcard lebih cocok digunakan untuk kelompok kecil yang tidak lebih dari 30 orang siswa (Susilana \& Riyana, 2009, hal. 94).

Dari paparan ahli di atas, dapat disimpulkan bahwa flashcard merupakan kartu dengan dua sisi. Sisi satu kosa kata yang dimiliki siswa dan siswa lebih mudah untuk mengingat setiap kosa kata. Flashcard hanya dapat dipakai pada kelas yang jumlah siswanya tidak lebih dari 30 siswa. Selain itu, ukuran flashcard yang akan dipakai di dalam kelas dapat disesuaikan dengan besar kelas yang diajar. Hal yang perlu diperhatikan dalam pemilihan kata-kata yang akan digunakan pada flashcard adalah dengan menggunakan kata-kata yang umum dan mudah dipahami oleh siswa. Dengan begitu, siswa dapat memahami kata yang siswa baca dan gambar yang diperlihatkan pada flashcard. Di bawah ini, pada gambar 1, adalah salah satu contoh flashcard yang sudah dibuat:

\section{Langkah-langkah Membuat Flashcard}

Di bawah ini akan diuraikan mengenai langkah-langkah membuat flashcard yang bisa dijadikan referensi. Menurut 
Susilana \& Riyana (2009, hal. 9596) langkah-langkah dalam membuat flashcard, sebagai berikut:

1. Siapkan kertas yang lumayan tebal, seperti kertas duplek. Kertas ini sebagai tempat untuk menempelkan gambar dan kata yang akan diajarkan dalam pembelajaran.

2. Kertas diukur dengan ukuran $25 \times 30 \mathrm{~cm}$ dan diberikan tanda lalu garis sesuai dengan tanda yang sudah diberikan.

3. Potonglah kertas yang sudah diukur, sehingga membentuk seperti kartu-kartu yang berukuran $25 \times 30 \mathrm{~cm}$. Potonglah kartu sesuai dengan jumlah gambar dan kata yang akan diajarkan.

4. Jika objek gambar dibuat langsung dengan tangan, maka kertas tersebut perlu dilapisi dengan kertas halus untuk menggambar, misalnya kertas HVS, kertas concort atau kertas karton.

5. Gambarlah dengan alat gambar, seperti kuas, cat air, spidol, pensil warna, atau membuat menggunakan desain menggunakan komputer dengan ukuran yang sesuai lalu langsung ditempelkan pada alas kertas tersebut.

6. Jika ingin menggunakan gambar yang sudah ada, misalnya gambar-gambar yang dijual di toko, di pasar, maka gambar tinggal dipotong dan ukurannya disesuaikan, kemudian ditempelkan menggunakan perekat.

7. Bagian akhir, berikan tulisan pada kartu-kartu tersebut sesuai dengan nama objek gambar yang telah ditempelkan.

Hal yang sama juga dikemukakan oleh Indriana (2011, hal. 136), yaitu dengan menyiapkan kertas yang cukup tebal, ukur kertas tersebut dengan ukuran $25 \times 30 \mathrm{~cm}$. Setelah kertas telah diukur, kertas tersebut dapat digunting sejumlah yang dibutuhkan. Dengan begitu, kertas yang telah digunting tersebut akan berbentuk kartu. Pada kartu tersebut, diberi gambar, gambar yang akan dimuat dapat merupakan gambar yang sudah ada, seperti yang terdapat pada toko atau di pasar, dapat juga gambar yang dibuat sendiri. Bisa juga memakai gambar yang sudah tersedia di internet. Gambar-gamar tersebut dicari dan disesuaikan dengan kebutuhan pembelajaran, kemudian dicetak dengan berwarnah penuh.

Bila gambar yang dimuat, merupakan gambar yang sudah ada, maka gambar tersebut tinggal dipotong dengan menyesuaikan ukuran katu yang telah dibuat. Bila gambarnya dibuat sendiri, maka kartu tersebut dapat dilapisi dengan kertas lagi sebagai alasnya, kemudian dapat mulai menggambar dengan alat gambar pada alas yang sudah disediakan. Sesudah itu, berilah tulisan yang sesuai dengan gambar yang telah ditempelkan pada setiap kartu. Tulisan sebaiknya berupa cetak dengan kombinasi warna-warna. 
Flashcard yang digunakan dalam pembelajran membaca permulaan ini diadopsi dan ada modifikasi dari langkah-langkah yang telah diuraikan oleh Susilana \& Riyana (2009) dan Indriana (2011), yakni sebagai berikut:

1. Menyiapkan kertas HVS sebagai tempat tulisan 'suku kata', 'kata' dan tempat gambar yang akan diajarkan pada pembelajaran membaca permulaan.

2. Kertas HVS tersebut dibuat berbentuk persegi dengan ukuran $8 \times 12 \mathrm{~cm}$. Bentuk persegi ini diukur dan disesuaikan dengan sentimeter yang ada dalam microsoft word.

3. Bentuk persegi yang telah diukur, diberikan bordir berwarna.

4. Persegi yang telah jadi kemudian diperbanyak sejumlah 20 persegi. Rinciannya adalah 10 persegi sebagai sisi depan kartu yang berisi tulisan "suku kata" dan "kata". Untuk 10 persegi yang lainnya sebagai sisi belakang kartu, yaitu isinya adalah gambar yang sesuai dengan kata yang tertulis.

5. Persegi untuk bagian sisi depan kartu dituliskan 'suku kata' dan 'kata' dengan warna yang berbeda pada setiap satu 'suku kata' dan 'kata' yang akan dipakai. Pada persegi bagian sisi belakang kartu diisi dengan gambar yang sesuai dengan kata yang telah dituliskan.

6. Persegi yang telah terdapat "suku kata", "kata", dan gambar pun diprint.

7. Persegi yang telah dicetak, langsung digunting, sehingga berbentuk seperti kartu-kartu.

8. Kartu bagian depan (berisi 'suku kata' dan 'kata) ditempelkan dengan kartu bagian belakang (berisi gambar) yang gambarnya sesuai dengan kata yang terdapat pada bagian depan. Dengan begitu, kartu yang telah dibuat berjumlah 10 kartu.

\section{Langkah-langkah Penerapan Flashcard}

Ada beberapa penerapan flashcard dari beberapa ahli yang akan dijelaskan pada bagian ini. Langkah-langkah penggunaan flashcard menurut Susilana dan Riyana (2009, hal. 16) sebagai berikut:

1. Kartu yang sudah disusun, dipegang setinggi dada dan dihadapkan kepada siswa.

2. Guru mencabut satu per satu kartu setelah selesai menjelaskan isi setiap kartunya.

3. Memberikan kartu yang telah dijelaskan kepada siswa yang berada di dekat guru, siswa tersebut diberikan waktu untuk mengamati dan mengulang kata dari huruf yang diberikan setelah itu. 
4. Media flashcard tersebut diteruskan kepada siswa lain yang berada di dekatnya hingga semua siswa mendapat bagian untuk melihat secara lagsung setiap media flashcard yang digunakan selama materi pembelajaran membaca huruf.

Langkah-langkah penggunaan flashcard menurut Indriana (2011, hal. 138-139) sebagai berikut:

1. Kartu-kartu yang sudah disusun dipegang setinggi dada dan menghadap siswa.

2. Cabutlah satu persatu kartu tersebut setelah guru selesai menerangkan.

3. Berikan kartu-kartu yang telah diterangkan kepada siswa yang duduk di dekat guru. Mintalah siswa itu mengamati kartu tersebut, lalu teruskan kepada siswa yang lain hingga semua siswa kebagian.

4. Jika sajian menggunakan jenis atau cara permainan, letakkan kartu-kartu tersebut dalam sebuah kotak secara acak dan tidak perlu disusun.

Berdasarkan langkah-langkah yang dikemukakan oleh dua ahli di atas, maka langkah-langkah penerapan flashcard yang diterapkan dalam pemebelajaran membaca permulaan adalah, sebagai berikut:

1. Guru menyusun kartu yang telah dibuat secara berurutan sesuai dengan kata-kata yang akan diajarkan.

2. Guru memegang susunan kartu yang sudah berurutan di depan kelas dan dipegang setinggi dada dan menghadap siswa. Usahakan kartu dapat dilihat oleh seluruh siswa dalam kelas.

3. Saat pembelajaran dimulai dengan flashcard, maka Guru akan mencabut satu per satu kartu yang telah dipersiapkan sembari menjelaskan isi setiap kartunya.

4. Setelah selesai menunjukkan kartu satu demi satu. Guru masih tetap memegang kartu tersebut untuk memberikan waktu kepada siswa mengamati dan mengulang setiap 'suku kata' serta 'kata' yang terdapat pada kartu tersebut secara bersamasama.

\section{Metode Penelitian}

Metode penelitian yang diterapkan adalah metode kualitatif deskriptif. Pada penelitian ini tidak ada data kualitatif atau berupa angkaangka statistik yang disajikan. Semua data dipaparkan secara deskriptif atau naratif. Seperti paparan para ahli diantaranya Sugiarto (2015, hal. 8) mengatakan bahwa "Penelitian kualitatif adalah jenis penelitian yang temuan-temuannya tidak diperoleh melalui prosedur statistik atau bentuk hitungan lainnya dan bertujuan mengungkapkan gejala secara holistik-kontekstual melalui pengumpulan data dari latar alami dengan memanfaatkan diri peneliti sebagai instrumen kunci". Yusuf berpendapat bahwa ada dua ciri penelitian deskriptif yaitu, "pertama, 
pemecahan masalah yang ada pada masa sekarang, atau masalah/kejadian yang aktual dan berarti, kedua, penelitian ini dimaksudkan untuk mendeskripsikan situasi atau kejadian secara tepat dan akurat, bukan untuk mencari hubungan atau sebab akibat" (2014, hal. 63). Menurut Wibowo (2011, hal. 43) "deskriptif-kualitatif adalah penggambaran secara kualitatif fakta, data, atau objek material yang bukan berupa rangkaian angka, melainkan berupa ungkapan bahasa atau wacana (apapun itu bentuknya) melalui interpretasi yang tepat dan sistematis". Untuk memperoleh data dalam penelitian ini menggunakan wawancara dan hasil observasi. Penelitian ini dilakukan di salah satu sekolah swasta yang ada di Mamit, Papua. Kelas yang di observasi adalah kelas $1 \mathrm{~B} \mathrm{SD.}$

\section{Analisis dan Pembahasan Penerapan Flashcard dalam Pembelajaran \\ hasil}

Berdasarkan

wawancara dan observasi bahwa ide awal untuk menerapkan flashcard dalam pembelajaran adalah dikarenakan saat pembelajaran, guru menemukan, ternyata siswa belum bisa membaca suku kata. Saat siswa diajar untuk membaca suku kata, yang terjadi adalah siswa hanya membunyikan satu persatu huruf dari suku kata yang ditunjuk. Selama proses pembelajaran berlangsung, terlihat bahwa siswa kelas 1 SD swasta Mamit, Papua, memang kesulitan membaca permulaan. Dengan latar belakang demikian, guru merancang Rencana Pelaksanaan Pembelajaran (RPP) dengan ide menerapkan flashcard pada pelajaran membaca permulaan.

flashcard dalam pelajaran membaca permulaan dirancang dalam dua pertemuan. Pada pertemuan pertama, guru terlebih dahulu menyusun RPP sesuai dengan langkah-langkah penerapan flashcard. Langkahlangkah ini diadopsi dan dimodifikasi sesuai kebutuhan pembelajaran dari teori yang sudah dipaparkan pada langkahlangkah penerapan flashcard. Pada langkah-langkah penerapan flashcard dimasukkan uraian materi pembelajaran dengan tema benda-benda yang ada di lingkungan sekitar. Pada dua sisi flashcard dipersiapkan gambar dan tulisan kata. Satu sisi dari flashcard berisi gambar dan di sisi lainnya berisi 'suku kata' dan 'kata' yang sesuai dengan gambar.

Adapun penerapan flashcard pada pertemuan pertama ini dapat dideskripsikan sebagai berikut ini: Setelah memulai pembelajaran dengan menyapa dan menjelaskan tujuan pembelajaran kepada siswa, guru langsung mengikuti langkah demi langkah penerapan flashcard. Guru menunjukkan flashcard kepada siswa dengan posisi setinggi dada, serta memperhatikan setiap siswa untuk memastikan bahwa seluruh siswa dapat melihat kartu. Untuk 
memastikan lagi, bahwa seluruh siswa dapat melihat kartu, guru mengajukan pertanyaan, "apakah bisa melihat media flashcard dengan baik?". Jawaban siswa menjadi penentu bahwa posisi flashcard sudah baik. Jika posisi flashcard sudah baik, maka guru siap melanjutkan ketahap berikutnya, yaitu, guru mulai menjelaskan tujuan dan kegunaan dari flashcard yang dipakai guru.

Setelah siswa mengetahui dan memahami tujuan dari penggunaan kartu tersebut, guru mulai menjelaskan nama benda yang ada pada gambar flashcard. Pada tahap berikutnya, kartu dibalik dengan menunjukkan tulisan "suku kata" dan "kata" sembari dibaca oleh guru. Tahap demi tahap dilakukan hingga sepuluh kartu yang sudah dipersiapkan ditunjukkan kepada siswa. Setelah selesai menjelaskan "kata", "suku kata" dan gambar melalui media flashcard, maka guru akan memberikan tes membaca kepada siswa satu per satu. Mekanismenya adalah siswa dipanggil satu persatu untuk membaca tulisan "kata" dan "suku kata" yang ada di kartu.

Pada pertemuan kedua penerapan flashcard, guru membagi siswa menjadi tiga kelompok sesuai dengan barisan tempat duduk siswa. Tujuannya adalah agar siswa bisa sekaligus diajari, dikoreksi dan sama-sama mengulang ketika guru meminta membaca "kata" dan "suku kata". Nama-nama kelompok diberi dengan abjad, yaitu A, B, dan C.
Guru menjelaskan materi pembelajaran dengan menerapkan flashcard pada pertemuan kedua ini, dengan mengikuti tahap-tahap penerapan seperti dalam pertemuan pertama. Guru mengangkat flashcard setinggi dada dengan menunjukkan "suku kata", "kata" dan gambar sembari menjelaskan satu persatu. Saat guru membacakan "suku kata" dan "kata" sembari diikuti oleh siswa secara bersama-sama. Guru menjelaskan kata benda yang terdapat pada bagian satu sisi flashcard dan satu sisi lagi gambar bendanya. Dengan memperlihatkan gambar, siswa dapat memahami benda konkretnya dan membaca "suku kata" dan "kata" dari benda tersebut. Setelah selesai menjelaskan materi pelajaran. Tiba saatnya bagi guru untuk memberi tes kepada setiap kelompok. Setiap kelompok yang ditunjuk guru akan maju ke depan kelas dan membunyikan huruf yang ada di kartu. Siswa akan dikoreksi secara langsung, jikalau masih ada siswa yang salah dalam membunyikan huruf yang ditunjuk, maka siswa akan mengulang bacaan dengan dituntun oleh guru dan diikuti oleh seluruh siswa dalam kelompok.

Kelompok yang akan maju digilir secara berurutan untuk menghadap guru. Setiap kelompok akan mendapat perlakuan yang sama. Saat memperbaiki yang salah dan diulang kembali, ada kalanya guru tidak akan membantu siswa 
dalam membacanya. Melainkan, siswa akan membaca sendiri atau membaca secara personal "kata" atau "suku kata" yang salah dibaca oleh siswa.

Setelah

pembelajaran

selesai membaca permulaan secara kelas, maka ada waktu yang disediakan oleh guru untuk melakukan tes individual terhadap siswa. Tujuannya adalah untuk mengukur dan mengetahui kemampuan siswa dalam membaca permulaan secara perorangan. Proses pelaksanaan tes ini akan memanggil setiap siswa satu per satu menghadap guru. Guru duduk di kursi dengan memegang flashcard, lalu siswa akan membaca "suku kata" dan "kata" yang ditunjukan oleh guru. Saat tes berlangsung, siswa lainnya yang tidak tes diberi aktivitas mandiri sembari menunggu giliran dipanggil untuk melakukan tes, yaitu meniru menggambar pemandangan yang digambar oleh guru. Di dalam gambar pemandangan tersebut, guru menyisipkan benda-benda yang mudah ditemui di sekitar sekolah. Seluruh siswa diminta untuk meniru gambar tersebut. Siswa yang ada di dalam kelas sangat senang menggambar dan setiap siswa akan tenang dan fokus bila diminta untuk menggambar.

Saat seluruh siswa sudah tenang menggambar, maka satu persatu siswa dipanggil untuk diberi tes membaca 'suku kata' dan 'kata' yang terdapat pada flashcard. Dengan begitu, setiap siswa dapat membaca tanpa ada peluang mendapat bantuan dari siswa lainnya. Dengan memanggil siswa satu per satu menghadap guru, maka akan lebih jelas bagi guru mendengarkan suara siswa dan lebih mudah juga untuk mengoreksi setiap kesalahan siswa.

\section{Manfaat dan Kendala Saat Menerapkan Flashcard Manfaat Penerapan Flashcard}

Dari hasil analisis penelitian ini ada beberapa manfaat yang diperoleh dengan menerapkan flashcard dalam pembelajaran membaca permulaan. Manfaat yang diperoleh adalah sebagai berikut:

1. Menarik perhatian siswa

Flashcard dapat
menarik perhatian siswa,
karena setiap tulisan "suku
kata" dan "kata", diberi warna
yang berbeda-beda untuk
membedakan antar "suku
kata" maupun "kata". Pada
bagian belakang flashcard
yang terdapat gambar, juga
diberi warna yang menarik.
Dengan adanya warna yang
berbeda-beda pada gambar,
"suku kata" dan "kata" dalam
flashcard tersebut, siswa tidak
bosan dan bisa menarik
perhatian siswa.
Ketertarikan siswa
dengan adanya flashcard
terlihat, yaitu awalnya
sebelum menggunakan
flashcard, saat pembelajaran
membaca, selalu
menggunakan papan tulis
untuk menulis "suku kata" dan
"kata". Setelah guru menulis


"suku kata" dan "kata" di papan tulis, kemudian siswa membaca secara bersama. Pada saat itu, terlihat banyak siswa yang tidak fokus dan siswa kurang tertarik melihat ke papan tulis. Ekspresi siswa yang terlihat adalah siswa memainkan pensil dan hanya mengikuti suara teman yang menyebut "suku kata" atau "kata" secara keras.

Namun, ada perbedaan dari respons siswa ketika mengajar membaca dengan menggunakan flashcard. Siswa terlihat fokus pada pembelajaran, yaitu respons yang diberikan siswa terlihat selalu menunggu kata demi kata dan gambar demi gambar dari setiap kartu yang perlihatkan. Siswa menunjukkan rasa penasaran untuk melihat gambar dan kata yang akan muncul pada kartu-kartu berikutnya.

Ketertarikan ini juga didukung bahwa siswa di Mamit sangat jarang melihat gambar dan tulisan kata yang penuh dengan warna-warna.

Selain itu, dengan adanya perbedaan warna pada setiap "suku kata" dan "kata, memudahkan siswa untuk membacanya. Siswa juga lebih fokus untuk membaca "suku kata" dan "kata" yang ada di flashcard, karena tidak ada gangguan dengan hadirnya "suku kata" dan "kata" yang lainnya. Kalau memakai papan tulis saja, maka tentunya ada "suku kata" dan "kata" lainnya berada secara berdekatan. Ini dilakukan tujuannya adalah agar tidak mengulang-ulang untuk menulis "suku kata" dan kata lainnya di papan tulis. Siswa juga telihat fokus dengan adanya warna pada setiap suku kata yang mereka baca.

2. Meningkatkan antusias siswa dalam membaca

Dari hasil diobservasi beberapa kali pengalaman guru yang mengajar membaca, apabila meminta siswa secara langsung untuk membaca sendiri "suku kata" dan kata yang ditunjuk oleh guru, maka banyak dari siswa yang ada di dalam kelas, seketika keringat dingin, tidak tenang, bahkan terdapat siswa yang menangis. Saat tiba pada pembelajaran membaca, beberapa siswa menunjukkan sikap dan wajah yang tegang. Sepertinya ada rasa khawatir dalam diri siswa, kalau ditunjuk guru untuk membaca, takutnya tidak bisa, sehingga menunjukkan ekspresi yang cemas.

Namun, saat menerapkan flashcard untuk pembelajaran membaca permulaan, siswa terlihat antusias dan semangat karena melihat gambargambar yang terdapat pada flashcard. Rasa penasaran siswa untuk belajar semakin bertambah. Dengan situasi dan kondisi yang demikian, suasana kelas semakin hidup dan meriah dan tidak tegang lagi. Ketika siswa ingin 
membaca, selalu ditekankan agar tetap fokus pada warna dari setiap "suku kata" dan "kata" yang ditunjuk. Ketika gambar yang sesuai dengan "suku kata" dan "kata" diperlihatkan, para siswa langsung bertepuk tangan kegirangan, karena senang melihat gambar tersebut.

3. Membantu daya ingat siswa Dalam penerapan flashcard terdapat satu langkah yang menuntun siswa untuk memerhatikan dan mengulang kembali membaca 'suku kata' dan 'kata'. Pengulangan ini dilakukan untuk memperbaiki atau mengoreksi ketika siswa salah membaca "suku kata" dan "kata" yang ada dalam flashcard. Setiap kesalahan akan diulang-ulang hingga siswa benar membacanya. Metode pengulangan, ada kalanya dilakukan secara acak dengan "suku kata" dan "kata" yang lainnya. Dengan adanya pengulangan tersebut, tentunya akan membantu siswa lebih mengingat 'suku kata' dan 'kata' yang sudah dipelajari.

\section{Kendala Penerapan Flashcard}

1. Butuh waktu yang lama untuk menerapkannya

Pada saat menerapkan flashcard pada pembelajaran membaca permulaan, ternyata membutuhkan banyak waktu, sehingga melebihi waktu yang sudah ditentukan untuk menjelaskan setiap "suku kata", "kata" dan gambar yang sudah dipersiapkan. Hal ini dapat terlihat saat penerapan flashcard tahap kedua, yaitu menjelaskan. Guru harus menjelaskan setiap kartu kepada siswa. Guru telah menyiapkan sepuluh kartu yang akan diajarkan kepada siswa, dengan demikian guru harus menjelaskan satu per satu dari sepuluh kartu tersebut. Pada langkah ketiga juga demikian, guru membacakan 'suku kata' dan 'kata' yang terdapat pada sepuluh flashcard yang selanjutnya diikuti oleh seluruh siswa. Dalam langkah ini juga dilakukan pengulangan. Untuk dapat memastikan bahwa siswa sudah mampu membaca permulaan, guru meminta siswa secara personal dan mandiri membaca "suku kata" dan "kata". Apabila siswa masih melakukan kesalahan dalam membaca, maka guru membantu siswa untuk mengulang kembali sampai benar. Dengan adanya pengulangan demi pengulangan, untuk memastikan siswa memahami pembelajran, sehingga membutuhkan waktu yang lama di dalam kelas.

2. Proses pembuatan flashcard butuh waktu yang lama Komponen yang terdapat pada flashcard adalah gambar dan tulisan "suku kata" dan "kata". Untuk membuat flashcard memerlukan waktu, yaitu 
mencari gambar-gambar yang bisa dimuat dalam kartu. Pemilihan gambar juga harus selektif agar gambar yang ditampilkan sesuai dengan karakter usia anak. Gambar yang dipilih juga harus bisa merepresentasikan "suku kata" dan "kata" yang akan dipelajari siswa. Gambar yang dipilih juga merupakah gambar yang umum dan mudah ditemukan dalam kehidupan sehari-hari. Pemilihan warna pada flashcard sebaiknya warna yang bisa menarik perhatian siswa. Dengan begitu, dalam mencari dan menentukan gambar yang akan dipakai pada flashcard membutuhkan waktu yang lama, karena mencari gambar dan menentukan gambar juga sulit.

\section{Kesimpulan}

Membaca

permulaan merupakan tahap awal yang diajarkan pada siswa kelas kecil. Membaca permulaan adalah mengajar siswa untuk mengenal huruf dan melafalkan bunyi dari setiap huruf, sehingga dari hurufhuruf tersebut, siswa dapat merangkai menjadi "suku kata" dan "kata". Setiap kata yang sudah terangkai tersebut tidak sekedar dilafalkan tetapi siswa dapat memahami maknanya. Oleh karena itu, untuk mengajar siswa membaca, bukanlah perkara yang mudah, sebab dalam mengajar membaca, siswa harus dituntun untuk mengerti konsep, bukan sekedar melafalkan.

Untuk mengajar siswa membaca permulaan, guru membutuhkan waktu yang lama dan kesabaran yang lebih. Salah satu upaya yang bisa dilakukan guru untuk membantu siswa mampu membaca "suku kata" dan "kata" adalah menerapkan flashcard. Flashcard merupakan kartu yang berisi kata pada sisi depan dan berisi gambar pada sisi belakang kartu. Flashcard sangat cocok digunakan untuk kelas satu SD, sebab kartu ini berisi gambar yang sesuai dengan "suku kata" dan "kata" serta diberi warna-warna yang berbeda untuk menarik perhatian siswa. Selain itu, gambar yang terdapat pada flashcard membantu siswa untuk mengingat kata yang sudah dibaca.

Saat proses penerapan flashcard di dalam kelas, ada manfaat dan kendala yang ditemukan oleh guru. Manfaat menerapkan flashcard diantaranya mampu menarik perhatian siswa, meningkatkan antusia untuk membaca atau tidak gugup lagi saat disuruh untuk membaca dan membantu daya ingat siswa. Kendala yang dihadapi guru adalah membutuhkan waktu yang lama untuk proses pembuatan dan penerapanya. Khususnya saat penerapan membutuhkan waktu yang lama, karena setiap kartu harus dijelaskan dan diulangulang untuk melatih siswa mampu membaca "suku kata" serta "kata". 


\section{Saran}

Saat guru hendak menerapkan flashcard, sebaiknya guru harus memastikan bahwa ia telah menguasai setiap langkahlangkah penerapannya. Apabila belum menguasai setiap langkah, kemungkinan siswa akan bingung mengikuti pembelajaran dan guru bisa tidak konsisten untuk menjelaskan maupun mengulang materi pembelajaran. Selain itu, saat membuat perencanaan untuk menerapkan flashcard, alokasikanlah waktu sebaik mungkin. Perlu diperhatikan bahwa langkah-langkah penerapan flashcard memang sedikit, tetapi saat diterapkan akan membutuhkan waktu yang banyak. Oleh sebab itu, mengatur waktu sangatlah penting, agar pembelajaran dengan menerapkan flashcard dapat terlaksana dengan baik hingga dapat memberi tes kepada siswa.

\section{ACUAN PUSTAKA}

Arsyad, A. (2014). Media pembelajaran. Jakarta: PT Raja Grafindo Persada

Budiningsih, C., A. 2005. Belajar dan pembelajaran. Jakarta: PT. Rineka Cipta

Dalman, H. (2013). Keterampilan membaca. Jakarta: PT Raja Grafindo Persada

Dewi, R. P. (2016). Peningkatan kemampuan membaca permulaan menggunakan media flashcard pada

siswa tunagrahita kategori ringan kelas 1 sekolah dasar di SLB Wiyata Dharma 2 Sleman Yogyakarta. Jurnal Widia Ortodidaktika, 5(9), 941949

Hotimah, E. (2010). Penggunaan media flashcard dalam meningkatkan

kemampuan siswa pada pembelajaran kosa kata bahasa Inggris kelas II MI Ar-Rochman Semarang Garut. Jurnal Pendidikan Universitas Garut, 4(1), 10-18. Diambil dari https://www.google.co.id/ url? sa $=\mathrm{t} \& \mathrm{rct}=\mathrm{j} \& \mathrm{q}=\& \mathrm{esrc}=$ s\&source $=$ web\&cd $=1 \& \mathrm{ca}$ $\mathrm{d}=$ rja\&uact $=8 \&$ ved $=0$ ahU KEwjTs OE4JjYAhVHto8 KHSb CVQQFgguMAA\& url=https\%3A\%2F\%2Fjou rnal.uniga.ac.id\%2Findex .php\%2FJP\%2Farticle\%2 Fdownload\%2F30\%2F30 \&usg=AOvVaw2ELIKZjSJ MM-6udkUbdZsx

Indriana, D. (2011). Ragam alat bantu media pengajaran. Jogjakarta: Diva Press

Irdawati, Yunidar, \& Darmawan. (2017). Meningkatkan kemampuan membaca permulaan dengan menggunakan media gambar kelas 1di Min Buol. Jurnal Kreatif Tadulako Online, 5(4), 114. Diambil dari https://media.neliti.com $/ \mathrm{m}$ 
edia/publications/121599-

ID-meningkatkan-

kemampuan-membaca-

permulaan.pdf

$$
\begin{array}{rr}
\text { Jamaris, } & \text { M. } \\
\text { Perkembangan } & \text { dan } \\
\text { pengembangan anak } \\
\text { usia taman kanak-kanak. } \\
\text { Jakarta: PT. Grasindo }
\end{array}
$$

Kusminah.

(2012).

Pengembangan model pembelajaran induktif kata bergambar bermuatan pendidikan nilai-nilai aspek karakter permulaan dasar. membaca Journal of Educational Research and Evaluation, 1(2), 113-119. Diambil dari file:///C:/Users/Windows \%208/Downloads/884-

Article\%20Text-1726-210-20121227.pdf

Maghfiroh,

$\mathrm{L}$.

(2013).

Penggunaan media flashcard untuk meningkatkan hasil belajar IPS pada pembelajaran tematik di Sekolah Dasar. Jurnal Pendidikan Guru Sekolah Dasar, 1(2), 0-216. Diambil dari https://www.google.co.id/ url? sa=t\&rct=i\&q=\&esrc= s\&source=web\&cd=3\&ca $\mathrm{d}=$ ria\&uact $=8 \&$ ved $=0$ ahU KEwjTs OE4JjYAhVHto8 KHSb CVQQFghBMAI\& url=http\%3A\%2F\%2Fejou rnal.unesa.ac.id\%2Farticl
e\%2F5200\%2F18\%2Farti cle.pdf\&usg=AOvVaw3F

VDfKKfD8t4GO8UEUnWS

Prastowo, A. (2017). Menyusun rencana pelaksanaan pembelajaran (RPP) tematik terpadu. Jakarta: Kencana. Diakses dari https://books.google.co.id /books?id= JBBDwAAQB AJ\&pg=PA43\&dq=proses tpembelajaran+adalah\&h I=en\&sa $=$ X\&ved=0ahUKE wjH6Mqz7JjYAhVluY8KH TeDA5MQ6AEIMDAB\#v= onepage \&q=proses $\% 20 p$ embelajaran\%20adalah\&f =false

Rahim, F. (2007). Pengajaran membaca di sekolah dasar. Jakarta: Bumi Aksara

Rahmawati. (2017). Strategi pembelajaran membaca dan menulis permulaan melalui media kata bergambar. Jurnal SAP. 1(3), 259-270. Diambil dari

file:///C:/Users/Windows \%208/Downloads/11593893-1-PB\%20(2).pdf

Sanjaya, W. (2008). Kurikulum dan pembelajaran (teori \& praktek KTSP). Jakarta: Prenadamedia Group. Diakses dari https://books.google.co.id lbooks?id=BJFBDwAAQ BAJ\&pg=PA227\&dq=pro ses+pembelajaran+adala 
Munthe \& Sitinjak, Manfaat serta Kendala Menerapkan Flashcard pada Pelajaran Membaca Permulaan

$\underline{h} \& h l=e n \& s a=X \& v e d=0 a h$

UKEwjH6Mqz7JjYAhVlu

Y8KHTeDA5MQ6AEIKTA

$\mathrm{A \# \textrm {V } = \text { onepage } \& \mathrm { q } = \text { proses }}$

\%20pembelajaran\%20ad

alah\&f=false

Sugiarto, E. (2015). Menyusun proposal penelitian kualitatif : skripsi dan tesis. Yogyakarta: Suaka Media. Diakses dari https://books.google.co.id /books?id=jWjvDQAAQB AJ\&printsec=frontcover\& $\mathrm{dq}=$ metode + penelitian $+\mathrm{k}$ ualitatif+adalah\&hl=en\&s a=X\&ved=0ahUKEwjtoo7 A-

17ZAhWHRY8KHfJbAbs Q6AEIQZAE\#V=onepage \&q=metode\%20penelitian \%20kualitatif\%20adalah\& $\underline{\mathrm{f}=\mathrm{false}}$

Susilana, R \& Riyana, C. (2009). Media pembelajaran hakikat, pengembangan, pemanfaatan, dan penilaian. Bandung: Wacana Prima

Sofiyah. (2014). Meningkatkan kemampuan membaca permulaan dengan menggunakan media gambar pada siswa kelas II SDN 2 Wosu Kecamatan Bungku Barat Kabupaten Morowali. Jurnal Tadulako Online, 3(2), 1-12. Diambil dari http://download.portalgar uda.org/article.php?articl $\mathrm{e}=174563 \& \mathrm{val}=5150 \&$ title =Meningkatkan\%20Kema
mpuan\%20Membaca\%20 Permulaan\%20dengan \% 20Menggunakan\%20Med ia\%20Gambar\%20pada \%20Siswa\%20Kelas\%20I \%20SDN\%202\%20Wos u\%20Kecamatan\%20Bun gku\%20Barat\%20Kabupa ten\%20Morowali

Tarigan, H. G. (2008). Membaca sebagai suatu keterampilan berbahasa. Bandung: Angkasa

Wibowo, W. (2011). Cara cerdas menulis artikel ilmiah. Jakarta: PT Kompas Media Nusantara. Diakses dari https://books.google.co.id /books?id=NDg9rcOjHU MC\&pg=PA44\&dq=peneli tian+deskriptif+kualitatif+ adalah\&hl=en\&sa $=$ X\&ved $=0$ ahUKEwiCl -

M Y7ZAhUK448KHT2VC qsQ6AEIVjAG\#v=onepag e\&q=penelitian\%20deskri ptif\%20kualitatif\%20adala $\underline{\mathrm{h} \& \mathrm{f}=\mathrm{false}}$

Windura, S. (2010). Memory champion@school. Jakarta: PT Elex Media Komputindo

Wahyuni, S. (2010). Cepat bisa baca. Jakarta: PT Gramedia. Diakses dari https://books.google.co.id /books?id=5P3Q4BILhNo C\&pg=PT12\&dq=cepat + b isa+baca\&hl=en\&sa $=X \& \mathrm{v}$ ed=0ahUKEwi99K7O24jZ AhXJa48KHRSyB7EQ6A 
ElJzAA\# $\mathrm{v}=$ onepage $\& \mathrm{q}=\mathrm{C}$ epat\%20bisa\%20baca\&f $=$ false

Yawu, S., Efendi, \& Barasandji, S. (2017). Peningkatan kemampuan siswa membaca permulaan melalui metode permainan bahasa di kelas I SDN Mire. Jurnal Kreatif Tadulako Online, 5(2), 52-63. Diambil dari http://download.portalgar uda.org/article.php?articl $\mathrm{e}=296279 \& \mathrm{val}=5150 \&$ title =Peningkatan\%20Keme mpuan\%20Siswa\%20Me mbaca\%20Permulaan\%2 0Melalui\%20Metode\%20 Permainan\%20Bahasa\% 20di\%20Kelas\%201\%20S DN\%20Mire

Yusuf, A. M. (2014). Metode penelitian: kuantitatif, kualitatif, dan penelitian gabungan. Jakarta: Kencana. Diakses dari https://books.google.co.id /books?id=RnA-

DwAAQBAJ\&pg $=$ PA63\&d q=penelitian+kualitatif+de skriptif+adalah\&hl=en\&sa =X\&ved=0ahUKEwiU8YS C-

47ZAhUBtl8KHd8kAfEQ6 AElbDAJ\# $\mathrm{v}=$ onepage $\& \mathrm{q}=$ penelitian\%20kualitatif\%2 0deskriptif\%20adalah\&f=f alse
World Health Organization (2012) Early childhood development and disability: a discussion paper. Geneva 27: WHO Press. Diakses dari http://apps.who.int/iris/bit stream/handle/10665/753 55/9789241504065_eng. pdf;jsessionid=AAAE2A8 17719C8210B430916C0 C87A5B? sequence $=1$ 